\title{
Toxicological and pharmacological evaluation of Discaria americana Gillies \& Hook (Rhamnaceae) in mice
}

\author{
Eliane Regina da Silva', Denise Diedrich¹, Rodrigo Cordeiro Bolzan², Sandro Rogério Giacomelli1,* \\ ${ }^{1}$ Department of Exact and Earth Sciences, Regional Integrated University of Alto Uruguai and Missões, ${ }^{2}$ Agricultural School \\ of Frederico Westphalen, Federal University of Santa Maria
}

\begin{abstract}
Medicinal plants (e.g. Discaria americana) have been used by populations for centuries. However, popular use is not enough to validate these plants as safe and effective medicinal products. The present study sought to evaluate the acute and subacute toxicity as well as the anxiolytic and antinociceptive effects of D. americana root bark and aerial parts extracts in mice. In acute toxicity studies, mice were treated with single intraperitoneal doses of the aforementioned extracts. Subacute toxicity studies were performed by oral administration of the extracts over 14 days. Anxiolytic studies consisted of the elevated plus maze method, and antinociceptive studies were based on the hot plate test. $\mathrm{Th} \mathrm{LD}_{50}$ value for $D$. americana aerial parts extract was established at $>500 \mathrm{mg} / \mathrm{kg}$, and for the root bark extract, $400 \mathrm{mg} / \mathrm{kg}$. D. americana aerial parts extract produced anxiolytic $(250 \mathrm{mg} / \mathrm{kg})$ and antinociceptive effects $(125,200$ and $250 \mathrm{mg} / \mathrm{kg})$. Conversely, $D$. americana root bark extract showed neither anxiolytic nor antinociceptive effects in mice.
\end{abstract}

Descriptors: Discaria americana/phamacognosy. Medicinal plants. Discaria americana/toxicological analysis. Discaria americana/acute toxicity. Discaria americana/subacute toxicity. Discaria americana/ anxiolytic effect. Discaria americana/antinociceptive effect.

\begin{abstract}
As plantas medicinais (i.e. Discaria americana) têm sido utilizadas pela população por séculos, entretanto, o conhecimento popular não é suficiente para validá-las como medicamentos seguros e/ou efetivos. Assim, o presente estudo teve por objetivo avaliar a toxicidade aguda e subaguda, bem como o efeito ansiolítico e antinociceptivo dos extratos da casca da raiz e das partes aéreas da $D$. americana em camundongos. A toxicidade aguda foi avaliada pela administração dos extratos, via intraperitoneal. Para o estudo da toxicidade subaguda os animais foram tratados oralmente com os extratos por 14 dias. O efeito ansiolítico dos extratos foi determinado através do modelo do labirinto em cruz elevado e o efeito antinociceptivo, mediante o teste da placa quente. $\mathrm{O}$ valor da $\mathrm{DL}_{50}$ para o extrato das partes aéreas da $D$. americana foi definido como $>500 \mathrm{mg} / \mathrm{kg}$, enquanto que para o extrato da casca da raiz foi estabelecido em $400 \mathrm{mg} / \mathrm{kg}$. O extrato das partes aéreas da D. americana apresentou atividade ansiolítica $(250 \mathrm{mg} / \mathrm{kg})$ e antinociceptiva $(125,200$ e $250 \mathrm{mg} / \mathrm{kg})$. O extrato da casca da raiz da $D$. americana não apresentou efeito ansiolítico nem antinociceptivo.
\end{abstract}

Unitermos: Discaria americana/farmacognosia. Palntas medicinais. Discaria americana/análise toxicológica. Discaria americana/toxicidade aguda. Discaria americana/toxicidade subaguda. Discaria americana/efeito ansiolítico. Discaria americana/efeito antinociceptivo.

\section{INTRODUCTION}

Medicinal plants have been used by populations for centuries. Even now, many plants play a key role in world health (Calixto, 2000). However, popular use is not enough to validate these plants as safe and effective medicines

*Correspondence: S. R. Giacomelli. Departamento de Ciências Exatas e da Terra, Universidade Regional Integrada do Alto Uruguai e das Missões. Rua Assis Brasil, 709, 98400-000 - Frederico Westphalen - RS, Brasil. E-mail: srgiacomelli@uri.edu.br
(Agra et al., 2007). Toxicity studies are required to evaluate the toxicity levels and adverse effects associated with medicinal plants. In addition to toxicity studies, study of the pharmacological activity of these plants is also important.

Discaria americana Gillies \& Hook is a shrub from the Rhamnaceae family. This plant is known by the common names "Quina-do-Brasil" and "Quina-do-RioGrande" (Brazil) or "Coronillo del campo" and "Quina del campo" (Uruguay) (Correa, 1984). D. Americana root bark is used by local populations against stomach and 
skin diseases, diabetes, fever (antipyretic), and as a tonic (Záchia, Moraes, 1999). However, almost no studies have assessed the toxicological and pharmacological properties of this plant; only one report, describing strong antioxidant activity of the essential oil extracted from the aerial parts of D. americana (Rodriguez, Murray, 2008), was located by a review of the literature.

The main chemical constituents of $D$. americana are pentacyclic triterpenes and steroids (Giacomelli, 2005). An important point is the presence of the triterpene ursolic acid, which has showed antioxidant (Ramachandram, Prasad, 2008), antinociceptive, anti-inflammatory (Tapondjou et al., 2003) and anti-cancer activities (Shao et al., 2011). The steroid $\beta$-sitosterol showed antioxidant (Yokota et al., 2006), antinociceptive (Cechinel Filho, Yunes, 1998), anti-cancer (Jourdain et al., 2006) and anti-inflammatory effects (Valerio, Awad, 2011). Furthermore, betulinic acid, a triterpene, has known anti-cancer, antinociceptive, anti-inflammatory, anti-HIV and antimicrobial activities (Yogeeswari, Sriram, 2005), as well as anxiolytic effects (Durst et al., 2002).

Cyclopeptide alkaloids and cyclopeptides (Giacomelli et al., 2004; Giacomelli, 2005) have also been isolated from $D$. americana. However, almost nothing has been reported on the toxic and pharmacological effects of these compounds. Among the alkaloids, frangulanine has a sedative effect, whereas discarine $\mathrm{A}$ and discarine $\mathrm{B}$ reportedly show antibacterial activity (Maldaner, 2005).

Some Rhamnaceae plants have been reported to show high levels of toxicity and adverse effects. Liver and lung damage and death have been observed in mice given Karwinskia humboldtiana (Bermudez et al., 1986). This plant also caused a decrease in ATP levels in the kidney and blood (Jaramillo-Juárez et al., 2005) and central nervous system damage in rats (Becerra-Verdin et al., 2009). Rhamnus cathartica, another plant from the same family, is known to be hepatotoxic in mice (Lichtensteiger et al., 1997). Therefore, according to the toxicity shown by other Rhamnaceae, evaluation of the toxicity of $D$. americana is paramount.

Thus, the present study sought to evaluate the acute and subacute toxicity of $D$. americana aerial parts and root bark extracts, as well as the potential anxiolytic and antinociceptive effects of these extracts, in mice.

\section{MATERIAL AND METHODS}

\section{Plant material}

D. americana root bark and aerial parts were col-

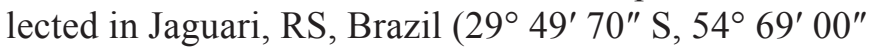
W) and authenticated by Dr. Renato Záchia, Department of
Botany, Universidade Federal de Santa Maria, RS, Brazil, where a specimen sample (SMDB 2688) is retained.

\section{Chemicals}

Dimethyl sulfoxide (DMSO) and methanol (MeOH) were obtained from VETEC Química Fina LTDA ${ }^{\circledR}$ (Rio de Janeiro, RJ, Brazil). Kits for clinical chemistry analysis of aspartate aminotransferase (AST) and alanine aminotransferase (ALT) were obtained from Labtest Diagnóstica S/ $\mathrm{A}^{\circledR}$ (Lagoa Santa, MG, Brazil). Paracetamol was obtained from Labsynth ${ }^{\circledR}$ (Diadema, SP, Brazil). Diazepam (DZP) was obtained from União Química Farmacêutica Nacional S/A ${ }^{\circledR}$ (Jabaquara, SP, Brazil).

\section{Preparation and identification of $D$. americana extracts}

Dried ground root bark $(1080 \mathrm{~g})$ and aerial parts $(1200 \mathrm{~g})$ of D. americana were extracted with methanol $(\mathrm{MeOH})(6 \mathrm{~L})$ in a Soxhlet apparatus for $12 \mathrm{~h}$. The resulting $\mathrm{MeOH}$ extracts were filtered and concentrated under vacuum, yielding the crude residues of the plant root bark and aerial parts ( 2.79 and $0.69 \%$ yield, respectively). The extracts were dissolved in dimethyl sulfoxide (DMSO) for administration in mice.

Four cyclopeptides were isolated from the root bark of $D$. americana (discarene $\mathrm{C}$, discarene $\mathrm{D}$, discarine $\mathrm{M}$ and discarine $\mathrm{N}$ ), as well as nine cyclopeptide alkaloids (adoutine $\mathrm{Y}$, adoutine $\mathrm{Y}^{\prime}$, franganine, frangulanine, discarine $\mathrm{A}$, discarine $\mathrm{B}$, discarine $\mathrm{C}$, discarine $\mathrm{D}$ and myrianthine $\mathrm{A}$ ), betulinic acid, and three steroids ( $\beta$-sitosterol, $\beta$-sitosterol-3-O-6- $\beta$-D-glucopyranoside and $\beta$-sitosterol-3-O-6-stearoyl- $\beta$-D-glucopyranoside). The steroids $\beta$-sitosterol and $\beta$-sitosterol-3-O-6- $\beta$-D-glucopyranoside, three pentacyclic triterpenes (betulinic acid, ursolic acid and ceanotic acid) and an ester derived from ferulic acid were isolated from the plant aerial parts. The isolated compounds were identified by direct comparisons with authentic samples by thin layer chromatography (TLC) and on the basis of NMR spectral data. TLC was performed on precoated silica gel $60 \mathrm{~F}_{254}$ plates $\left(\right.$ Merck $\left.^{\circledR}\right)$ (mobile phase: mixture of $\mathrm{CHCl}_{3}$ and $\mathrm{MeOH}$ ) and detection was achieved by UV light (254 nm), by spraying with Dragendorff's reagent, and by spraying with $10 \% \mathrm{H}_{2} \mathrm{SO}_{4}$, followed by heating (Giacomelli et al., 2004; Giacomelli, 2005).

\section{Animals}

Healthy mice (Mus musculus) of either sex (1:1), weighing 35-45 g, obtained from our own breeding fa- 
cilities, were kept in an air-conditioned room $\left(22 \pm 2{ }^{\circ} \mathrm{C}\right)$, under a 12-hour light/dark cycle (lights on at 8:00 a.m.), with water and food (Nuvital ${ }^{\circledR}$ chow, PR, Brazil) ad libitum. A total sample of 270 mice was used for toxicity and pharmacology studies. For each test, animals were divided into groups of 10 animals. The experiments were carried out with the approval of the Universidade Regional Integrada do Alto Uruguai e das Missões Research Ethics Committee (protocol no. 023/07).

\section{Acute toxicity studies}

Groups of 10 mice were injected with single doses of $D$. americana root bark extract $(50,100,300,400$ and $500 \mathrm{mg} / \mathrm{kg})$, plant aerial parts extract $(500 \mathrm{mg} / \mathrm{kg})$ and DMSO (control). The dose of $500 \mathrm{mg} / \mathrm{kg}$ was established as the highest dose of the plant extract for determination of $\mathrm{LD}_{50}$. Mice were injected intraperitoneally, as this route of administration is associated with rapid absorption, thus enabling evaluation of exposure during a short period of time.

Signs of general toxic effects, such as weight loss, seizures, or death, were observed continuously for $2 \mathrm{~h}$ and then monitored over a 48 -hour period. After $48 \mathrm{~h}$, animals were euthanized and necropsied for gross observation of the heart, kidneys and liver, as well as blood sample collection. The study was carried out as by Maciel et al. (2000), with the exception of exposure time (48 hours).

\section{Subacute toxicity studies}

D. americana root bark extract (50 and $100 \mathrm{mg} / \mathrm{kg}$ ) and aerial parts extract (300 and $400 \mathrm{mg} / \mathrm{kg}$ ) were administered to groups of 10 mice by once-daily gavage for 14 days. Control group animals received the vehicle (DMSO) under the same conditions. Toxic manifestations, such as seizures, weight loss, and death, were monitored daily. At the end of the 14-day period, animals were euthanized and necropsied for macroscopic observation of the heart, kidneys and liver, as well as blood sample collection. Again, the study was carried out as by Maciel et al. (2000), except for the route of administration.

\section{Blood analysis}

Blood was collected in heparinized tubes and used immediately. Tubes were centrifuged at $3000 \mathrm{rpm}$ for $10 \mathrm{~min}$ to obtain serum, which was then analyzed. Transaminase (AST and ALT) activity was determined enzymatically as described by Bergmeyer (1978), using commercial kits from Labtest Diagnóstica $\mathrm{S} . \mathrm{A}^{\circledR}$ in a semiautomatic LABQUEST ${ }^{\circledR}$ biochemical analyzer.

\section{Evaluation of anxiolytic effect}

The elevated plus maze (EPM) method was used to assess the anxiety level of mice. The maze consists of two opposed open arms and two opposed enclosed arms, bounded by $30-\mathrm{cm}$ high walls. Each arm measures $50 \times 10 \mathrm{~cm}$, with a shared central area of $10 \times 10 \mathrm{~cm}$. The maze is kept $50 \mathrm{~cm}$ above the floor.

Single doses of $D$. americana root bark extract $(50,100$ and $200 \mathrm{mg} / \mathrm{kg})$, aerial parts extract (125 and $250 \mathrm{mg} / \mathrm{kg}$ ), DMSO (placebo control) and diazepam $1.5 \mathrm{mg} / \mathrm{kg}$ (positive control) were administered intraperitoneally to groups of 10 mice.

One hour after treatment, mice were placed on the central area of the maze. The number of entries into the enclosed and open arms was recorded, as was the time spent in each arm. Time spent in the open arms was considered as the measure of anxiolytic effect (Pellow et al., 1985).

\section{Evaluation of antinociceptive effect}

The experiment started 60 min (time zero) after intraperitoneal administration of $D$. americana root bark extract $(50,100$ and $200 \mathrm{mg} / \mathrm{kg}$ ) and aerial parts extract $(125,200$ and $250 \mathrm{mg} / \mathrm{kg})$ to groups of 10 mice. Animals were placed individually on a hot plate kept at a constant temperature of $55^{\circ} \mathrm{C}$. The time to first paw lick (henceforth "latency") was recorded. Measurements were performed at $0,15,30$ and 60 min after the first thermal stimulus. To avoid damage to the animals' paws, the maximum time spent on the plate was $30 \mathrm{~s}$. Therefore, a latency period of $30 \mathrm{~s}$ was defined as complete antinociception (Ankier, 1974). For comparison, the same experiment was conducted with paracetamol $400 \mathrm{mg} / \mathrm{kg}$ (positive control) and DMSO (control).

\section{RESULTS AND DISCUSSION}

\section{Acute toxicity}

To assess acute toxicity of $D$. americana, mice were injected with aerial parts and root bark extracts and with DMSO (control). During the experiment, the occurrence of adverse affects and the mortality of mice were observed. The maximum dose of $500 \mathrm{mg} / \mathrm{kg}$ of $D$. americana aerial parts extract did not cause death in mice; hence, the $\mathrm{LD}_{50}$ value was established as $>500 \mathrm{mg} / \mathrm{kg}$ (Table I).

According to Saraswat et al. (1996), ursolic acid, a triterpene constituent of $D$. americana, has hepatoprotective activity. However, acute administration of the plant aerial parts extract at the dose of $500 \mathrm{mg} / \mathrm{kg}$ caused 
TABLE I - Effect of acute and subacute administration of $D$. americana extracts on mortality in mice. $N=10$

\begin{tabular}{lcc}
\hline Treatments & Dose $(\mathrm{mg} / \mathrm{kg})$ & Mortality $(\%)$ \\
\hline Acute toxicity & & \\
Control & - & 0.0 \\
Root bark extract & 50 & 0.0 \\
& 100 & 0.0 \\
& 300 & 40.0 \\
& 400 & 50.0 \\
& 500 & 60.0 \\
Aerial parts extract & 500 & 0.0 \\
\hline Subacute toxicity & & \\
Control & - & 0.0 \\
Root bark extract & 50 & 10.0 \\
& 100 & 20.0 \\
Aerial parts extract & 300 & 0.0 \\
& 400 & 20.0 \\
\hline
\end{tabular}

a significant increase in transaminase (ALT and AST) levels (Table II). High serum levels of these enzymes are a marker of injury, usually liver damage. Furthermore, autopsy of these animals revealed a variable number (1 to 4) of opalescent oval lesions, approximately $0.5 \mathrm{~cm}$ in diameter, on the liver. These hepatic lesions were observed in $70 \%$ of animals.

TABLE II - Effect of acute administration of $D$. americana extracts on serum transaminase levels $(\mathrm{U} / \mathrm{L})$ in mice

\begin{tabular}{lccc}
\hline Treatments & $\begin{array}{c}\text { Dose } \\
(\mathrm{mg} / \mathrm{kg})\end{array}$ & $\begin{array}{c}\text { ALT } \\
(\mathrm{SGPT})\end{array}$ & $\begin{array}{c}\text { AST } \\
(\mathrm{SGOT})\end{array}$ \\
\hline Control & - & $52.4 \pm 6.8$ & $363.6 \pm 28.6$ \\
\hline & 50 & $104.4 \pm 33.6^{*}$ & $359.2 \pm 57.9$ \\
Root bark & 100 & $145.7 \pm 6.9^{*}$ & $364.0 \pm 40.9$ \\
extract & 300 & $186.0 \pm 38.5^{*}$ & $348.7 \pm 41.8$ \\
& 400 & - & $516.0 \pm 80.4^{*}$ \\
\hline Aerial parts & 500 & $101.4 \pm 34.9^{* *}$ & $425.8 \pm 60.4^{* *}$ \\
extract & & &
\end{tabular}

Values are expressed as mean \pm standard deviation. $N=4-10$.

(*) Statistically different from controls, $\mathrm{p}<0.05$ (ANOVA/ Tukey's test). (**) Student's $t$ test.

Acute administration of $D$. americana root bark extract caused mortality proportional to the administered doses. At the highest dose level $(500 \mathrm{mg} / \mathrm{kg})$, the mortality rate was $60 \%$. The $\mathrm{LD}_{50}$ was established as $400 \mathrm{mg} / \mathrm{kg}$. At this dose, there was a significant increase in AST levels.
At $300 \mathrm{mg} / \mathrm{kg}, 40 \%$ of mice died, and half of those that survived showed evidence of liver injury and significantly increased ALT levels. At the dose of 50 and $100 \mathrm{mg} / \mathrm{kg}$, there was no mortality, but ALT levels were increased as compared to mice in the control group.

The weight of mice that survived acute exposure was evaluated $48 \mathrm{~h}$ after administration of the extracts. There was no significant weight loss in mice treated with D. americana extracts as compared to the control group. Furthermore, there was no significant difference in liver weight/body weight of mice treated with $D$. americana in relation to the control group (Table III).

TABLE III - Effect of acute and subacute $D$. americana exposure on weight and liver weight/body weight of mice

\begin{tabular}{lccc}
\hline Treatments & $\begin{array}{c}\text { Dose } \\
(\mathrm{mg} / \mathrm{kg})\end{array}$ & $\begin{array}{c}\text { Initial } \\
\text { weight } \\
(\%)\end{array}$ & $\begin{array}{c}\text { Liver weight/ } \\
\text { body weight } \\
(\%)\end{array}$ \\
\hline Acute toxicity & - & $105.2 \pm 7.3$ & $5.01 \pm 0.90$ \\
\hline Control & 50 & $95.0 \pm 3.0$ & $4.90 \pm 0.23$ \\
\hline & 100 & $93.0 \pm 6.0$ & $5.64 \pm 1.40$ \\
Root bark extract & 300 & $90.6 \pm 9.6$ & $5.85 \pm 0.87$ \\
& 400 & $92.9 \pm 2.5$ & $6.37 \pm 0.37$ \\
\hline Aerial parts extract & 500 & $93.0 \pm 8.1$ & $5.27 \pm 0.79$ \\
\hline Subacute toxicity & & & \\
\hline Control & - & $104.0 \pm 5.2$ & $5.10 \pm 0.49$ \\
\hline Root bark extract & 50 & $97.8 \pm 4.4$ & $4.86 \pm 0.41$ \\
\hline Aerial parts extract & 100 & $91.5 \pm 5.7 *$ & $5.30 \pm 0.80$ \\
\hline & 400 & $105.2 \pm 7.3$ & $4.84 \pm 0.52$ \\
\hline
\end{tabular}

Values are expressed as mean \pm standard deviation. $N=4-10$. (*) Statistically different from controls, $\mathrm{p}<0.05$ (ANOVA/ Tukey's test).

No macroscopic changes were observed in the kidneys and hearts of mice treated with $D$. americana extracts. Furthermore, there was no significant difference in kidney weight or heart weight/body weight of mice treated with $D$. americana in relation to the control group. No seizure activity was observed in acute toxicity studies. There were no deaths or adverse effects in the control group.

\section{Subacute toxicity}

For assessment of subacute toxicity, D. americana extracts and DMSO were orally administered to mice for 
14 days. General toxic effects and mortality were observed during the treatment period. At a dose of $400 \mathrm{mg} / \mathrm{kg}$, the aerial parts extract caused $20 \%$ mortality (Table I), moderate weight loss (Table III), and a significant increase in ALT and AST levels (Table IV). At $300 \mathrm{mg} / \mathrm{kg}$, there were no deaths or significant weight loss, although ALT and AST levels did increase.

TABLE IV - Effect of subacute administration of $D$. americana extracts on serum transaminase levels $(\mathrm{U} / \mathrm{L})$ in mice

\begin{tabular}{lccc}
\hline Treatments & $\begin{array}{c}\text { Dose } \\
(\mathrm{mg} / \mathrm{kg})\end{array}$ & ALT (SGPT) & AST (SGOT) \\
\hline Control & - & $88.7 \pm 18.2$ & $360.2 \pm 65.7$ \\
\hline Root bark extract & 50 & $119.0 \pm 25.7$ & $482.1 \pm 46.3^{*}$ \\
\hline Aerial parts extract & 100 & $169.3 \pm 40.2^{*}$ & $491.5 \pm 31.0^{*}$ \\
\hline
\end{tabular}

Values are expressed as mean \pm standard deviation. $N=8-10$.

(*) Statistically different from controls, $\mathrm{p}<0.05$ (ANOVA/ Tukey's test).

At a dose of $100 \mathrm{mg} / \mathrm{kg}$, D. americana root bark extract led to significant weight loss and increased ALT and AST levels, as well as a $20 \%$ mortality rate. A dose of $50 \mathrm{mg} / \mathrm{kg}$ was associated with $10 \%$ mortality and increased serum AST levels, but no significant weight loss.

The greater toxicity of $D$. americana root bark extract as compared to the aerial parts extract can be attributed to the alkaloids present in the root bark. A review of the literature showed that some of these alkaloids have known toxic effects in mice (Tabosa et al., 2006). Furthermore, some alkaloids are toxic - mainly hepatotoxi - in humans (Bolzan et al., 2007).

No macroscopic changes were observed in the liver, kidneys and heart of mice treated with $D$. americana extracts. There were no significant differences in the ratio of weight of these organs to body weight in mice treated with D. americana as compared to the control group. No seizure activity was observed in subacute toxicity studies. There were no deaths and no adverse effects in the control group.

Although important parameters were evaluated in these acute and subacute toxicity studies, further assessments are needed before intake of $D$. americana can be considered safe in humans.

\section{Pharmacology}

This study evaluated the anxiolytic effect of $D$. americana in mice using the elevated plus maze (EPM) method. The potential antinociceptive effect of the plant was evaluated with the hot plate test. No toxic doses or doses that showed lower toxicity effects were used in the pharmacology portion of this study. These doses were determined according to acute toxicity studies. For $D$. americana root bark extract, $50 \mathrm{mg} / \mathrm{kg}\left(1 / 8 \mathrm{LD}_{50}\right), 100 \mathrm{mg} / \mathrm{kg}$ $\left(1 / 4 \mathrm{LD}_{50}\right)$ and $200 \mathrm{mg} / \mathrm{kg}\left(1 / 2 \mathrm{LD}_{50}\right)$ doses were used. The aerial parts extract of $D$. americana showed a $\mathrm{LD}_{50}$ of $>500 \mathrm{mg} / \mathrm{kg}$. At this dose, toxic manifestations were observed; therefore, half of this dose $(250 \mathrm{mg} / \mathrm{kg})$ was used for pharmacology studies. The 125 and $200 \mathrm{mg} / \mathrm{kg}$ doses were also used in pharmacological studies in order to evaluate the possibility of a dose-dependent effect.

In the anxiolytic studies, the control group spent most of the $10 \mathrm{~min}$ in the enclosed arms of the EPM, indicating anxiety. Data showed an increase in time spent in the open arms among mice treated with $D$. americana aerial parts extract at the dose of $250 \mathrm{mg} / \mathrm{kg}$. This reduction in anxiety could be associated with ursolic acid, an important component of the aerial parts of $D$. americana that has known anxiolytic properties (Durst et al., 2002). A similar effect occurred in the positive control group (DZP $1.5 \mathrm{mg} / \mathrm{kg}$ ). D. americana root bark extract had no anxiolytic effect (Table V).

TABLE V - Time spent in open arms of the elevated plus maze after exposure to $D$. americana extracts

\begin{tabular}{lcc}
\hline Treatments & Dose $(\mathrm{mg} / \mathrm{kg})$ & $\begin{array}{c}\text { Time spent in open } \\
\text { arms }(\%)\end{array}$ \\
\hline Control & - & $23.0 \pm 7.4$ \\
\hline \multirow{2}{*}{ Root bark extract } & 50 & $42.2 \pm 12.8$ \\
\hline Aerial parts extract & 100 & $37.8 \pm 14.5$ \\
\hline Diazepam & 200 & $42.6 \pm 13.7$ \\
\hline
\end{tabular}

Values are expressed as mean \pm standard deviation. $N=10$.

(*) Statistically different from controls, $\mathrm{p}<0.05$ (ANOVA/ Tukey's test).

Antinociceptive studies revealed that mice treated with $D$. americana aerial parts extract at a dose of $125 \mathrm{mg} / \mathrm{kg}$ had a significant reduction in nociceptive response at 0 and $15 \mathrm{~s}$. The $200 \mathrm{mg} / \mathrm{kg}$ dose caused a significant increase in latency at all periods analyzed. At a $250 \mathrm{mg} / \mathrm{kg}$ dose, the nociceptive response was $>30 \mathrm{~s}$. A trend toward dose-dependent increase in the analgesic effect of $D$. americana aerial parts extract was observed. This striking antinociceptive potential of $D$. americana 
TABLE VI - Effect of D. americana extracts on hot plate test latency in mice

\begin{tabular}{lccccc}
\hline \multirow{2}{*}{ Treatments } & \multirow{2}{*}{ Dose $(\mathrm{mg} / \mathrm{kg})$} & \multicolumn{4}{c}{ Latency $(\mathrm{s})$} \\
\cline { 3 - 5 } & & 0 & 15 & 30 & 60 \\
\hline Control & - & $12.7 \pm 5.6$ & $13.5 \pm 5.2$ & $18.2 \pm 7.6$ & $22.0 \pm 3.3$ \\
\hline \multirow{3}{*}{ Root bark extract } & 50 & $18.7 \pm 5.1$ & $17.0 \pm 3.7$ & $29.0 \pm 2.0$ & $28.5 \pm 2.3$ \\
& 100 & $25.7 \pm 4.9$ & $23.0 \pm 5.5$ & $26.2 \pm 7.5$ & $27.5 \pm 5.0$ \\
& 200 & $24.2 \pm 11.5$ & $18.2 \pm 9.8$ & $27.0 \pm 3.8$ & $29.5 \pm 1.0$ \\
\hline \multirow{3}{*}{ Aerial parts extract } & 125 & $28.7 \pm 2.5^{*}$ & $29.7 \pm 0.5^{*}$ & $21.0 \pm 2.0$ & $26.0 \pm 5.2$ \\
& 200 & $29.5 \pm 0.5^{*}$ & $28.7 \pm 1.8^{*}$ & $29.5 \pm 0.5^{*}$ & $30.0 \pm 0.0^{*}$ \\
\hline Paracetamol & 250 & $30.0 \pm 0.0$ & $30.0 \pm 0.0$ & $30.0 \pm 0.0$ & $30.0 \pm 0.0$ \\
\hline
\end{tabular}

Values are expressed as mean \pm standard deviation. $N=10$.

(*) Statistically different from controls, $\mathrm{p}<0.05$ (ANOVA/Tukey's test).

can be ascribed to three components that are present in the plant: the triterpenes ursolic acid (Tapondjou et al., 2003) and betulinic acid (Yogeeswari, Sriram, 2005) and the steroid $\beta$-sitosterol (Cechinel Filho, Yunes, 1998), which are known antinociceptive agents. Pretreatment of animals with paracetamol $(400 \mathrm{mg} / \mathrm{kg})$, the positive control used in this study, also caused a significant antinociceptive effect (nociceptive response $>30 \mathrm{~s}$ ). Conversely, $D$. americana root bark extract did not reduce the nociceptive response in mice (Table VI).

In conclusion, the present study showed that $D$. americana root bark extract produces toxic effects at low doses and was not successful as an anxiolytic or antinociceptive agent. Conversely, an aerial parts extract of the same plant showed low toxicity even when administered at the highest doses, and successfully reduced anxiety and nociception in mice. However, to protect human health, further toxicity studies are necessary if this plant is to be used as a herbal remedy. On the basis of the findings reported herein, $D$. americana can be considered a promising source for development of new anxiolytic and analgesic agents.

\section{ACKNOWLEDGMENTS}

The authors would like to thank the National Council for Scientific and Technological Development (CNPq), the Rio Grande do Sul State Department of Science and Technology (SCT), and Fundação Regional Integrada do Alto Uruguai e das Missões (FURI) for their financial support.

\section{REFERENCES}

AGRA, M.F.; FRANÇA, P.F.; BARBOSA-FILHO, J.M. Synopsis of the plants known as medicinal and poisonous in Northeast of Brazil. Rev. Bras. Farmacog., v.17, n.1, p.114-140, 2007.

ANKIER, S.I. New hot plate tests to quantify antinociceptive and narcotic-antagonist activities. Eur. J. Pharmacol., v.27, n.5, p.1-4, 1974.

BECERRA-VERDIN, E.M.; BERMÚDEZ-BARBA, M.V.; SALAZAR-LEAL, M.E.; RODRÍGUEZ, J.A.; ROMERODIAZ, V.; SOTO-DOMÍNGUEZ, A.; BALLESTEROSELIOZONDO, R.G.; SAUCEDO-CARDENAS, O.; LOPEZ, A.P.; SAAVEDRA, J.S. Karwinskia humboldtiana (buckthorn) fruit causes Central Nervous System damage during chronic intoxication in the rat. Toxicon, v.53, n.6, p.645-651, 2009.

BERGMEYER, H.U.; SCHEIBE, P.; WAHLEFELD, A.W. Optimization of methods for aspartate aminotransferase and alanine aminotransferase. Clin. Chem., v.24, n.1, p.5873, 1978 .

BERMUDEZ,M.V.; GONZALEZ-SPENCER，D.; GUERRERO, M.; WAKSMAN, N.; PIÑEYRO, A. Experimental intoxication with fruit and purified toxins of buckthorn (Karwinskia humboldtiana). Toxicon, v.24, n.11-12, p.1091-1097, 1986. 
BOLZAN, A.A.; SILVA, C.M.; FRANCESCATO, L.N.; MURARI A.L.; SILVA, G.N.S.; HELDWEIN, C.G.; HEINZMANN, B. Espécies de Senecio na medicina popular da América Latina e toxicidade relacionada a sua utilização. Lat. Am. J. Pharm., v.26, n.4, p.619-625, 2007.

CALIXTO, J.B. Efficacy, safety, quality control, marketing and regulatory guidelines for herbal medicines (phytotherapeutic agents). Braz. J. Med. Biol. Res., v.33, n.2, p.179-189, 2000.

CECHINEL FILHO, V.; YUNES, R.A. Estratégias para a obtenção de compostos farmacologicamente ativos a partir de plantas medicinais. Conceitos sobre modificação estrutural para otimização da atividade. Quím. Nova, v.21, n.1, p.99-105, 1998.

CORREA, M.P. Dicionário de plantas úteis do Brasil e das exóticas cultivadas. Rio de Janeiro: Imprensa Nacional, 1984. p.568.

DURST, T.; MERALI, Z.; ARNASON, J.T.; SANCHEZVINDAS, E.P.; POVEDA, A.L. Anxiolytic Marcgraviaceae compositions containing betulinic acid, betulinic acid derivates, and methods. WO/2002/091858. US Patent 7488722. 2002.

GIACOMELLI, S.R.; MALDANER, G.; GONZAGA, W.A.; GARCIA, C.M.; SILVA, U.F.; DALCOL, I.I.; MOREL, A.F. Cyclic peptide alkaloids from the bark of Discaria americana. Phytochemistry, v.65, n.7, p.933-937, 2004.

GIACOMELLI, S.R. Estudo fitoquímico de três espécies pertencentes à família Rhamnaceae: Discaria americana, Colletia paradoxa e Gouania ulmifolia. Santa Maria, 2005. 333p. [Thesis of PhD degree. Department of Chemistry. Federal University of Santa Maria].

JARAMILLO-JUÁREZ, F.; RODRÍGUEZ-VÁZQUEZ, M.L.; MUÑOZ-MARTÍNEZ, J.; QUEZADA-TRISTÁN, T.; POSADAS DEL RIO, F.A.; LLAMAS-VIRAMONTES, J.; ORTÍZ, G.G.; FERIA-VELASCO, A.; REYES, J.L. The ATP levels in kidneys and blood are mainly decreased by acute ingestion of tullidora (Karwinskia humboldtiana). Toxicon, v.46, n.1, p.99-103, 2005.

JOURDAIN, C.; TENCA, G.; DEGUERCY, A.; TROPLIN, P.; POELMAN, D. In-vitro effects of polyphenols from cocoa and [beta]-sitosterol on the growth of human prostate cancer and normal cells. Eur. J. Cancer Prev., v.15, n.4, p.353-361, 2006.
LICHTENSTEIGER, C.A.; JOHNSTON, N.A.; BEASLEY, V.R. Rhamnus cathartica (Buckthorn) hepatocellular toxicity in mice. Toxicol. Pathol., v.25, n.5, p.449-452, 1997.

MACIEL, E.N.; BOLZAN, R.C.; BRAGA, A.L.; ROCHA, J.B.T. Diphenyl diselenide and diphenyl ditelluride differentially affect $\delta$-aminolevulinate dehydratase from liver, kidney, and brain of mice. J. Biochem. Mol. Toxicol., v.14, n.6, p.310-319, 2000.

MALDANER, G. Estudo dos metabólitos secundários da Condalia buxifolia e Scutia buxifolia e suas atividades antimicrobianas. Santa Maria, 2005. 96p. [Dissertation of Master degree. Department of Chemistry. Federal University of Santa Maria].

PELLOW, S.; CHOPIN, P.; FILE, S.E.; BRILEY, M. Validation of open closed arm entries in an elevated plus maze as a measure of anxiety in the rat. J. Neurosci. Meth., v.14, n.3, p.149-167, 1985.

RAMACHANDRAM, S.; PRASAD, N.R. Effect of ursolic acid, a triterpenoid antioxidant, on ultraviolet-B radiationinduced cytotoxicity, lipid peroxidation and DNA damage in human lymphocytes. Chem.-Biol. Interact., v.176, n.2/3, p.99-107, 2008.

RODRIGUEZ, S.; MURRAY, A.P. Volatile components of Discaria americana Gillies \& Hook (Rhamnaceae). Nat. Prod. Res., v.22, n.3, p.253-257, 2008.

SARASWAT, B.; VISEN, P.K.S.; DAYAL, R.; AGARWAL, D.P.; PATNAIK, G.K. Protective action of ursolic acid against chemical induced hepato-toxicity in rats. Ind. J. Pharmacol., v.28, n.4, p.232-239, 1996.

SHAO, J.; DAI, Y.; XUE, J.; WANG, J.; LIN, F.; GUO, Y. In vitro and in vivo anticancer activity evaluation of ursolic acid derivatives. Eur. J. Med. Chem., v.46, n.7, p.26522661, 2011.

TABOSA, I.M.; QUINTANS-JÚNIOR, L.J.; PAMPLONA, F.V.; ALMEIDA, R.N.; CUNHA, E.V.L.; SILVA, M.S.; SOUZA, J.C.A.; BARBOSA FILHO, J.M. Isolamento biomonitorado de alcalóides tóxicos de Prosopis juliflora (algaroba). Rev. Bras. Farmacol., v.9/10, n.1, p.11-22, 2006. 
TAPONDJOU, L.A.; LONTSI, D.; SONDENGAM, B.L.; CHOI, J.; LEE, K.; JUNG, H.; PARK, H. In vivo antinociceptive and anti-inflammatory effect of the two triterpenes, ursolic acid and 23-Hydroxyursolic acid, from Cussonia bancoensis. Arch. Pharm. Res., v.26, n.2, p.143146, 2003.

VALERIO, M.; AWAD, A.B. $\beta$-Sitosterol down-regulates some pro-inflammatory signal transduction pathways by increasing the activity of tyrosine phosphatase SHP-1 in J774A.1 murinemacrophages. Int. Immunopharmacol., v.11, n.8, p.1012-1017, 2011.

YOGEESWARI, P.; SRIRAM, D. Betulinic acid and its derivatives: a review on their biological properties. Curr. Med. Chem., v.12, n.6, p.657-666, 2005.
YOKOTA, J.; TAKUMA, D.; HAMADA, A.; ONOGAWA, M.; YOSHIOKA, S.; KUSUNOSE, M.; MIYAMURA, M.; KYOTANI, S.; NISHIOKA, Y. Scavenging of reactive oxygen species by Eriobotrya japonica seed extract. Biol. Pharm. Bull., v.29, n.3, p.467-471, 2006.

ZÁCHIA, N.R.B.; MORAES, D. Estudo taxonômico dos gêneros Discaria Hooker e Colletia Commerson ex Jussieu (Rhamnaceae) no Rio Grande do Sul. Pesq. Bot., v.49, n.3, p.121-142, 1999.

Received for publication on $17^{\text {th }}$ August 2011 Accepted for publication on $13^{\text {th }}$ March 2012 